\title{
Real Wages in Pakistan: Structure and Trends, $1970-84^{1}$
}

\author{
MOHAMMAD IRFAN and MEEKAL AZIZ AHMED*
}

\section{INTRODUCTION}

The structure of wages in any economy has profound implications for labour utilization, income distribution and the incentive to invest in human capital. This paper aims at measuring and analysing the level and trend of nominal and real wages in different sectors of the economy of Pakistan for the 1970-84 period. The broad patterns of wage change are then looked at in terms of their implications for employment promotion, human capital formation and other related policy issues. The analysis is based on the best available information but the usual caveats appropriate to empirical work in Pakistan apply.

The pattern of wages at the broad sectoral level in Pakistan has not been well explored. Thus far, only two researchers have endeavoured to address this question. Guisinger and Hicks [4] examined the indices of real wages/incomes in four major sectors: agriculture, large-scale manufacturing, government employees and the urban informal sector. Their analysis showed that, except those for government employees, real wages improved for all categories of workers in the '60s. A major source of the improvement in real wages in agriculture and the urban informal sectors was the rapid pace of growth in agriculture while institutional forces such as labour and wage policies were responsible for the rise in the real wages of production workers in large-scale manufacturing. There appeared to have been a narrowing in wage differentials between the formal and informal sectors, which, according to the authors, furnished presumptive evidence of an improvement in income distribution in Pakistan.

In a second study, Irfan [7] investigated inter-sectoral wage trends in the urban areas of the economy, using data for roughly the same time period. According to his analysis, all workers, including government servants, experienced a gain, albeit a

* The authors are, respectively, Chief of Research at the Pakistan Institute of Development Economics, Islamabad, and Chief, Planning and Development Division, Government of Pakistan, Islamabad. The authorsare thankful to Abdul Majeed Naeem, Research Officer, Planning Division, for his assistance in compilation and analysis of data.

${ }^{1}$ This is a substantially edited version of an earlier paper presented at the Second Annual General Meeting of the Pakistan Society of Development Economists in May 1985. Almost all statistical tables have been removed. These are available from the authors on request. 
modest one, in real wage in the '60s. In the case of government employees, a distinction was made between the rates at the time of entry into a job specified by the pay scales and the wages of public employees. The author concluded that the latter must have improved because the annual increments, generally around $3-5$ percent of the basic pay, were higher than the rise in the cost-of-living index. The rise in the real wages of production workers in manufacturing was ascribed to an interaction of market and non-market forces while the improvement in real wages in the urban informal sector was attributed to the growth in that sector and in agriculture, the pace of urbanization and, possibly, a spill-over effect of 'protected' sector wage settlements. Taken together, these trends pointed to a modest contraction in the wage structure (which appeared to have been partially reversed in the early '70s) but any strong inference about movement in wage differentials and income distribution was precluded by the low share of wages in total income.

The purpose of this paper is to extend the analysis undertaken in the earlier studies for the 1970-84 period. In what follows, we first describe briefly the pattern of wage-income trends in four major sectors: large-scale manufacturing, government employment, agriculture and the urban informal sector. The data are presented in Appendix Tables I and II. This is followed by a discussion of the forces responsible for generating these trends. The implications of the changing structure of earnings for the labour absorptive capacity of the economy and other relevant policy aspects are then addressed in the final section. ${ }^{2}$

\section{FORMAL SECTOR WAGE STRUCTURE}

\section{Wages in Large-scale Manufacturing}

The trend in the wages of production workers in the large-scale manufacturing sector during the 1960-70 period has been investigated by a number of researchers. Khan [8] found that in the 1954-63 period real wages declined. Guisinger and Irfan [3], using a broader definition of wages to include non-cash benefits and a longer time period (1954-70), concluded that real wages improved, with most of the gain having occurred in the late ' $60 \mathrm{~s}$. For the subsequent period, there has been no comprehensive study of real wage trends in large-scale manufacturing covering all Pakistan, although one study by Ahmed and Naeem, subsequently updated to include the years 1972-84 [1], analysed real wage trends in six key manufacturing industries in the Punjab province in the 1972-82 period.

Table 1 presents information on nominal- and real-wage trends of production and non-production workers in the large-scale manufacturing sector for the 1970-81

${ }^{2}$ It is well to note that the average wage at the sectoral level is a high aggregative concept and masks large variations around it. Furthermore, comparisons of inter-sectoral wage movements assume that the skill mix of employment in each sector has undergone a broadly uniform ments assume that the skill mix
change during the period studied. period based on information that is now available from the published Census of Manufacturing Industries (CMI) reports. Since CMI reports are not available for all the years, we have chosen to present the data in terms of two sub-periods: $1970-76$ and 1976-81. This is not only convenient but important analytically since the trends in the two sub-periods differ markedly. The lack of a comprehensive time suries on an all-Pakistan basis is partly made up for by the time-series data that are available for six major manufacturing industries in the Punjab for the years 1972-84 (see Appendix Table I).

Table 1

Nominal-and Real-wage Trends in Large-scale Manufacturing 1970-81

(Percent per annum)

1970-76 1976-81

I. Nominal Wages

All Workers

Production Workers

15.8

17.3

Non-production Workers

16.6

II. Real Wages

All Workers

Production Workers

Non-production Workers

III. Consumer Prices

14.4 9.5

Source: [11], various issues.

As Table 1 shows, nominal wages of production workers rose persistently throughout the eleven-year period at roughly the same rate in both sub-periods, i.e. by about 17-18 percent per annum. By contrast, the earnings of non-production workers increased less sharply in the first sub-period but accelerated thereafter to a rate close to 20 percent per annum. However, this surge in nominal wages was not translated into commensurate gains in real wages. Because of the acceleration of consumer price inflation in the 1970-76 period, much of the rise in money wages was offset so that real wages of production workers rose by only 2.9 percent per year while the real earnings of non-production workers actually stagnated. However, it must be noted that this rise in real wages is extremely sensitive to the choice of end-points, viz. 1969-70 and 1975-76. Shifting the base year to 1970-71, for example, suggests that no increase in real wages occurred; some other studies suggest a possible decline [7]. In the latter period, however, these trends were sharply 
reversed. Since the fall in inflation was not matched by a slowing in nominal wage increases, real wages rose for both categories of workers during the 1976-81 period.

We may summarize this section as follows. Real wages of production and nonproduction workers more or less stagnated during the 1970-76 period but turned sharply upwards thereafter. As shown by the CMI data, the differences in the rate of increase of money wages between production and non-production workers in the two sub-periods suggest a widening in differentials in favour of the former category of workers; but this is almost entirely eliminated following the much sharper acceleration in money wages of non-production workers in the latter period. Although one finds that non-production workers (as a group) managed to regain the edge of 1969-70 over production workers, this may not be true for the sub-group of managerial workers. The available CMI data on the wages of managerial workers for 1970-71 and 1975-76 clearly suggest a decline in their relative position vis-a-vis production and other non-production workers.

\section{Real Wages of Government Employees}

The earnings of government employees include a variety of benefits in addition to the basic wage. Since information on some of these components such as medical and pension benefits is hard to come by, estimates of total earnings for various categories of government employees is subject to an unknown margin of error. Government pay scales are revised periodically, largely in response to the perceived erosion in real living standards caused by inflation and during the period of our study, the national pay scales were revised three times: in 1972, 1977 and 1983. In addition ad-hoc relief measures were often announced and these were subsequently incorporated in the revised pay scales.

The available data (see Appendix Table II) show that, when measured in terms of 1969-70 constant purchasing power, the basic pay of government employees underwent a significant deterioration except in the case of employees in the lowest pay category (Grade 1) where a rise of some 18 percent occurred between 1972 and 1983. In terms of total earnings, which include all benefits except medical and pension benefits, the lower level employees in Grades 1-5 and Grade 17 appear to have been protected by the 1983 pay scales. The pay scales announced in 1977 provided such protection to the lowest paid categories only. Thus, during the period from 1972 to 77, all employees except those in Grades 1 and 17 experienced a significant deterioration in real wages. A similar comparison in the 1977-83 period suggests a marginal rise in the real value of total earnings in all categories except the top five grades (Grades 18-22). It is to be noted, however, that the rise in the real value of earnings in the 1977-83 period was still insufficient to bring real earnings back to their 1972 levels except for those employed in Grades 1-6 and 17. Overall, real earnings fell with the sharpest decline having occurred in Grades 18-22. The higher increase in pay afforded to low paid employees has resulted in a significant reduction in differentials in pay with the ratio of Grade 1 to Grade 22 employees in terms of basic pay having declined from 30.1 to 10.1 ; the corresponding decline in terms of total earnings was from 26.1 to 13.1 .

\section{INFORMAL SECTORS}

\section{Wages in Agriculture}

The measurement of wages in Pakistan's agricultural sector represents a rather neglected field. With the exception of the study by Guisinger and Hicks [4] there has been no systematic investigation of the subject. This is largely a reflection of the severe constraints of data. The present study can only hope to make a modes contribution to information on the subject based on a patchwork of data for the 1973-84 period. As these data show (see Appendix Table I) real wages in the agriculture sector declined between 1974 and 1975, turned upwards thereafter and reached in 1980 the level recorded in the year 1974. A further increase in real wages was experienced in 1981 followed by stagnation. Nevertheless, real wages in 1984 were around 10 percent higher than those reported for 1974.

\section{Wages in the Construction Sector}

The only evidence on wage movement in urban informal sector is that which pertains to wages of a few categories of workers in the construction sector which are collected and published regularly by NESPAK and the Federal Bureau of Statistics. The general pattern which emerges from a consideration of the data (see Appendix Table I) is one of decline in real wages in the early ' 70 s followed thereafter by a fairly persistent rise until 1980. Subsequently, real wages stagnated or declined for most of the categories of workers.

\section{THE SOURCE OF WAGE CHANGES}

The evidence presented above is suggestive of a general rise in real wages of all categories of workers except government employees. However, the improvement in real wages did not occur at a uniform pace; in most cases studied, real wages remained static or increased marginally during the $1970-75$ period and then followed an upward course in the 1976-81 period. For the large-scale manufacturing sector, the data on six industries in the Punjab show that the positive trend in real wages was sustained up to 1984 . The wages in agriculture and construction exhibit near constancy for the most recent sub-period (1981-83), however. The factors underlying these changes are briefly discussed below. 


\section{Emigration}

Emigration, a spontaneous response to increased demand for labour in the Middle East, appears to be a major force bearing upon labour market conditions in Pakistan. The exodus of labour from Pakistan, which commenced in the early ' 70 s, rose rapidly in volume and peaked in 1980-81. Thereafter the net outflow of workers has tended to stagnate. Thus, over a short span of a decade or so, around two and a half million workers emigrated to the Middle East countries [5]. The sharp reduction in labour supply that this out-migration engendered was not, however, the only factor affecting the labour market in Pakistan. An equally important factor has been the inflow of workers' remittances and their use. Thus, the intertemporal confluence of these two flows influenced labour market conditions both through the supply side - by reducing the labour supply - and through the demand side - i.e. through strong aggregate demand pressures arising from the expenditure of the remittance income.

The link between out-migration and wage levels is, however, modified by a conjuncture of a number of factors. Institutional intervention in the wage determination process such as the enactment of wage policies and trade union pressures will help to shape and modify the adjustment process of wages in the 'protected' or formal sectors of the economy. Similarly there is the scope for substitution across occupations and between labour and capital. Finally, changes in demand stemming from the patterns of expenditure out of remittances may accentuate or moderate the supply effects of labour out-migration on wage levels in the domestic market.

The direct effect of labour exodus on wage levels has been investigated earlier by Irfan [6]. Making a comparison of the incomes reported for different occupational categories in the Household Income and Expenditure Surveys of 1971-72 and 1979, Irfan concluded that the larger percentage gain in income of production and service workers relative to professionals reflected the impact of out-migration. In order to support the contention that labour exodus directly contributed to the rise in the real wage in informal sectors, Irfan regressed the average real wage of carpenters and masons taken together against the stock of labour in the Middle East for the 1971-82 period. The equation clearly showed that the latter variable explained more than half of the variance of the former and was highly singificant. ${ }^{3}$

The trend of nominal and real wages in the large-scale manufacturing sector did not remain immune to the progressive tightening of the labour market in the

\footnotetext{
${ }^{3}$ The regression equation was:
}

$W C O N=14.25+0.005$ STK

$\bar{R}^{2}=.056$ (3.890)

where $W C O N$ is the average of the daily real wage of carpenters and masons in Karachi, and STK is the stock of labour in the Middle East in thousands. The figure in parenthesis is the t-ratio. informal sectors. A time-series regression of real wages of production workers in the six manufacturing industries in the Punjab shows that real wages were strongly correlated with productivity changes and with the stock of labour in the Middle East. ${ }^{4}$ The latter variable may be seen to exert a direct positive influence on the course of wage settlements in manufacturing, or serve as a proxy for the tightness in the domestic labour market. The only labour market segment which appears to have remained immune to the influence of emigration is that of government employees where wages were subject to the parameters laid down by the National Pay Scales and thereby lagged behind the rate of inflation in the '70s.

\section{Institutional Intervention}

The Government's labour and wage policies and trade union 'pushfulness' constitute the mechanism of institutional intervention in the wage determination process. The introduction of the new labour policy in early 1970 extended a number of benefits to labour. The enactment of these measures during a period when the economy was beset by stagnation in the commodity-producing sectors and high inflation, and insignificant out-migration, failed to improve the real standards of workers in the manufacturing sector in the 1972-76 period. While the workers in the unprotected informal sectors may have benefited partly from the spill-over effects of these wage policies, their real wages in 1974 were in fact lower than that recorded in 1970 [7].

Although the high domestic inflation experienced during the early ' 70 s contributed to the near stagnation of the living standard of workers in the large-scale manufacturing sector, the resistence of trade unions to a fall in their real wage is manifest in the very high level of strike activity during 1975-76. It is following this period, however, that the exodus of labour gathered momentum, stimulating wage increases in the unprotected informal sectors like construction, which, in turn, exerted a strong upward push to wage trends of production workers in the largescale manufacturing sector. This is clearly borne out by both the CMI and the Punjab data for the 1976-81 and 1976-84 periods respectively. In addition, although strike activities were banned by the military regime after 1977 and no wage or labour policy was or has since been announced, the possibility that trade unions continued to influence the outcome of wage settlements through collective bargaining pressures cannot be ruled out.

${ }^{4}$ The equation for the $1972-82$ period is:

$\log _{2} R W=-2.669+0.754 \log P R T Y+0.463 \log S T K$

$$
\bar{R}^{2}=.975 \quad(2.736) \quad(19.891)
$$

where $R W=$ real wage of production workers; $P R T Y=$ productivity; $S T K=$ stock of workers in the Middle East, and the figures in parenthesis are t-values. 


\section{IMPLICATIONS OF WAGE CHANGES}

In the preceding sections we have discussed the overall trends and structure of wage changes in Pakistan's economy and identified the principal factors that underlay these developments. In this final section an attempt is made to draw out some of the implications of these changes for the labour absorptive capacity of the economy, the incentives for individuals to invest in human capital and the long-run sustainability of the existing structure of differentials.

\section{Employment Generation}

One of the most significant developments to have occurred in recent years has been the substantial and widespread decline in the elasticity of employment with respect to real output growth in all major sectors of the economy. Of course, not all of the decline in the employment elasticity can be attributed to wage cost pressures; but the unprecedented rise in wages over the past decade certainly provided an important stimulus to the choice of more capital-intensive techniques. In agriculture, for example, during the 1973-83 period, the number of tractors imported was over five times the total number existing in 1973, a trend which sharply reinforced the mechanization already under way in the form of threshers and harvesters. Clearly, the farmer's investment decision was influenced by outmigration - estimated at about 8 percent of the rural male labour force - its attendant labour shortage, and the rise in wages that followed. The degree of labour utilization in other sectors such as construction also appears to have fallen. The extensive use of conveyor belts, vibrators, crushers and mixers is suggestive of the widespread displacement of labour in this sector. According to one estimate, labour requirements per unit of output in construction fell by about $20-30$ percent during the 1975-82 period [6].

The CMI data on manufacturing industry permit a closer look at what has happened to employment growth in this sector. During the 1970-76 period, as shown by Table 2, total manufacturing employment rose by 3.3 percent per annum largely on account of the rapid growth in employment of production workers (4.9 percent per annum). Since manufacturing output rose by only 4.3 percent per year, the arc elasticity of employment with respect to output growth yielded by these data is 0.767 . Between 1976 and 1981 total employment in large-scale manufacturing dropped by some 55000 workers or by 2.2 percent per year with almost two-thirds of the decline in the textile sector alone. Since real manufacturing output expanded by 12.3 percent per year, the fall in employment yielded negative employment elasticity $(-0.186)$ compared with an elasticity of 0.76 in the previous six years and a long-term elasticity of about 0.5 [1].
Table 2

Changes in Output, Employment Costs, Prices and Productivity, Large-scale Manufacturing: 1970-81

(Percent per annum)

1970-76
1976-81

I. Output 4.3

12.3

II. Employment

Total

Production Workers

III. Cost, Prices and Labour's Share Unit wage cost

Ratio of value added to output

Producers' prices

Labour's share in value added

IV. Productivity and Factor Intensity

Labour productivity

Capital productivity

Capital-labour ratio

Source: [11], various issues; [10], various issues.

The most plausible explanation for the fall in employment during the 1976-81 period is that it represented the unwinding of a long lagged response to the disappointingly low output and demand levels in the early ' 70 s and the severe cost pressures experienced by manufacturing industry in these years. But it appears that employers shed labour rather earlier and faster than in previous periods of slow growth by adopting the most capital-intensive technique available - a search touched off by the earlier explosion of wages and the near stagnation of labour productivity grow th which had combined so powerfully to squeeze manufacturers' profit margins.

Although the large-scale manufacturing sector found itself in a 'virtuous circle' of rising productivity and profits in the $1976-81$ period and it was thereby able to recoup some of the ground lost during the stagflation of the early ' 70 s, the implications of this recovery have been severely damaging to employment growth. Of course, one could argue that as output and productivity growth is consolidated and employment returns to levels more consistent with changed factor costs and prices, a continuing demand growth will bring a return to positive employment growth as well. However, the important point to note is that any prospective slowing in productivity growth will have to be matched by an easing in real wage growth if renewed 
cost pressures and a further shift towards labour-displacing technologies are to be avoided. The more recent data that are available for the manufacturing sector of the Punjab show that neither of these presumptions has been fulfilled. Earnings and productivity growth remained strong up to 1984, and although the continuing rapid growth in productivity has provided an important foundation for more restrained unit cost and price increases, the pressure on manufacturers to rebuild their profit margins through further adjustment in manning practices and investment in more capital-intensive plant and equipment has remained great. The recent fall in the employment elasticity in large-scale manufacturing could, in our view, prove to be irreversible at least over the medium term.

\section{Erosion of Education Margins}

The general compression of the wage structure has substantially diminished the relative advantage of being educated. This compression of wages is borne out by both inter- and intra-sectoral comparisons. The differentials in pay between production workers and managers in the large-scale manufacturing sector have narrowed and a similar tendency is evident in a comparison of the wage of a lower level government employee compared with the earnings of the higher-level staff. In an inter-sectoral comparison, one finds that the real wage of government employees has fallen sharply. The decline in the real content of the entry rates implicit in the government pay scales relative to the rates of wages earned by an unskilled labourer and carpenter in the construction sector led to a rise in the ratio of the informalformal pay structure. This rise is more pronounced when a comparison is made between the informal sector worker and a senior government official (Grades 19 and above). Given that the majority of the output of the educational institutions in Pakistan is absorbed in the services sector, particularly as public employees, the relative deterioration in government wage scales may adversely bear upon the incentive to invest in human capital.

Not only the relative but the absolute differentials in pay, generally regarded as more appropriate to decisions to invest in human capital [2], have moved in favour of unskilled and semi-skilled workers. In 1983, for example, an unskilled labourer earned the equivalent to the earnings of a staff member in Grade 5. This is equivalent to a Lower Division Clerk, with the minimum entry qualification being Matric. The relative edge of a highly educated professional underwent a diminution. A Grade 18 officer in 1972 earned Rs. 646 more than a carpenter; this differential was reduced to Rs. 210 by 1983 . Similarly, a Grade 20 employee in 1972 was worth 7 to 8 carpenters but in 1983 his conversion ratio approximated to 3 in terms of constant purchasing power.

How far the fall in differentials in pay has affected rates of return to education merits careful investigation. Since decisions regarding educational investment are based on large-term considerations, it could be argued that the recent compression of the wage structure has had only a marginal effect on educational investment decision. However, the limited success in raising the enrolment rate and the literacy ratio along with the failure of the educational system to arrest drop-out rates could well be explained in terms of the adverse repercussions of the change in the structure of wages.

\section{CONCLUSIONS}

The evidence presented above suggests that with the exception of government employees, the average wage earner in Pakistan enjoyed a higher real wage in 1984 than in 1970. Most of the improvement in real wages occurred in the eight-year period from 1976 to 1984 in contrast to the near stagnation and, in some cases a decline, in the earlier period, 1970-75. The improvement in real wages has been broad-based: wage earners both in the informal sectors such as agriculture and construction, and the formal sectors such as large-scale manufacturing, experienced a rise in their real wages. Government employees were an exception to this general trend. The unequal rates at which real wages have been augmented has led to a narrowing in the differentials in pay between the formal and informal sectors. This is evident from the reduction in the differentials between the wages of the less educated and the highly educated or members of the professional and managerial class.

A major factor which has determined the level and structure of wage trends has been a sharp reduction in labour supply occasioned by emigration and the return flow or workers' remittances. Since these forces are potentially reversible and unrelated to the productive structure of the economy, they have posed a number of problems. The shift from the commodity-producing sector to the service sector of the economy has been attended by a significant reduction in the economy's labour absorptive capacity. While the service orientation of the economy can be attributed to the expenditure pattern of remittances income, the widespread fall in labour use primarily stems from the rise in wage costs per unit of output. The adoption of more capital-intensive techniques of production in agriculture, manufacturing and construction at a time when the economy is faced with the prospect of an accelerating flow of returnees has potentially serious consequences for future employment growth.

The high incidence of migration amongst the less educated and semi-skilled workers, in conjunction with domestic wage policies designed to protect the living standards of low-wage employees, has led to a narrowing of the wage differential between the educated and the less educated. The presumption that this narrowing in differentials has tended to be egalitarian is not supported by data on income distribution since wage incomes account for less than one-third of total incomes. The 


\section{Appendix Table I}

Nominal and Real Wages of Workers in Different Sectors of Pakistan's Economy 1970-84

\begin{tabular}{|c|c|c|c|c|c|c|c|c|c|c|c|c|}
\hline \multirow{5}{*}{ Year } & \multicolumn{4}{|c|}{$\begin{array}{l}\text { Production Worker in Large Scale } \\
\text { Manufacturing }\end{array}$} & \multicolumn{6}{|c|}{$\begin{array}{l}\text { Construction Worker Wages. } \\
\text { Rs/Day }\end{array}$} & \multirow{2}{*}{\multicolumn{2}{|c|}{$\begin{array}{l}\text { Agriculture Unskilled } \\
\text { Labour Rs/Day }\end{array}$}} \\
\hline & \multicolumn{2}{|c|}{ All Pakistan } & \multicolumn{2}{|c|}{ Six Major Ind. Punjab } & \multicolumn{2}{|c|}{ Carpenter } & \multicolumn{2}{|c|}{ Masons } & \multicolumn{2}{|c|}{ Unskilled Labour } & & \\
\hline & Money & Real & Money & Real & Money & Real & Money & Real & Money & Real & Money & Real \\
\hline & Wages & Wages & Wages & Wages & Wages & Wages & Wages & Wages & Wages & Wages & Wages & Wages \\
\hline & \multicolumn{4}{|c|}{ Rs/Month } & & & & & & & & \\
\hline $1969-70$ & 167 & 167 & N.A. & N.A. & 12.2 & 12.0 & 13.0 & 13.0 & 5.1 & 5.1 & N.A. & N.A. \\
\hline $1970-71$ & 183 & 173 & N.A. & N.A. & 13.0 & 12.3 & 13.5 & 12.7 & 55 & 5.1 & N.A. & N.A. \\
\hline $1971-72$ & N.A. & N.A. & 163 & 147 & 13.9 & 12.5 & 14.5 & 13.4 & 5.4 & 4.9 & N.A. & N.A. \\
\hline $1972-73$ & N.A. & N.A. & 175 & 144 & 14.2 & 11.7 & 15.0 & 12.3 & 5.7 & 4.7 & 5.8 & 4.7 \\
\hline $1973-74$ & N.A. & N.A. & 219 & 138 & 18.6 & 11.8 & 19.0 & 12.0 & 8.6 & 5.4 & 7.9 & 5.0 \\
\hline $1974-75$ & N.A. & N.A. & 282 & 145 & 25.0 & 12.5 & 25.1 & 12.6 & 11.8 & 5.9 & 7.5 & 3.8 \\
\hline $1975-76$ & 435 & 194 & 324 & 145 & 30.0 & 13.4 & 30.0 & 13.4 & 14.5 & 6.5 & 7.7 & 3.5 \\
\hline $1976-77$ & N.A. & N.A. & 351 & 144 & 37.0 & 15.2 & 38.3 & 15.7 & 17.9 & 7.3 & 9.1 & 3.7 \\
\hline $1977-78$ & 625 & 240 & 382 & 147 & 45.0 & 17.3 & 46.5 & 17.8 & 21.3 & 8.2 & 10.0 & 3.8 \\
\hline $1978-79$ & 712 & 253 & 420 & 149 & 49.5 & 17.5 & 49.8 & 17.6 & 22.8 & 8.1 & 11.7 & 4.2 \\
\hline $1979-80$ & N.A. & N.A. & 518 & 167 & 57.7 & 18.5 & 57.7 & 185 & 24.3 & 7.8 & 14.7 & 4.7 \\
\hline $1980-81$ & 938 & 266 & 594 & 169 & 61.1 & 17.2 & 63.7 & 18.0 & 26.5 & 7.5 & 19.5 & 5.5 \\
\hline $1981-82$ & N.A. & N.A. & 677 & 171 & 69.0 & 17.5 & 69.1 & 17.5 & 29.0 & 7.3 & 20.0 & 5.0 \\
\hline $1982-83$ & N.A. & N.A. & 760 & 184 & 69.0 & 16.8 & 72.0 & 17.6 & 30.7 & 7.3 & 20.5 & 5.0 \\
\hline $1983-84$ & N.A. & N.A. & 881 & 196 & N.A. & N.A. & N.A. & N.A. & N.A. & N.A. & 23.2 & 5.2 \\
\hline
\end{tabular}

Notes: 1. Real wages are arrived at by using the consumer price index $1969-70=100$.

2. Production worker wages for all Pakistan are based on Census of Manufacturing Industries. While Punjab data pertain to six major industries of Punjab.

3. Construction sector wages are taken from Price Index NESPAK various issues.

4. Agriculture worker wages are taken from I.L.O. year book for 1973-1978. For 1979-80 to 1981-82 wages are the average of I.L.O. year book and the ones reported in "Cost of Production of Major Crops as reported by leading farmers in Punjab" Government of Pakistan, Planning Division.

For 1982-84 wages are taken from a survey conducted by PIPO. (unpublished). 


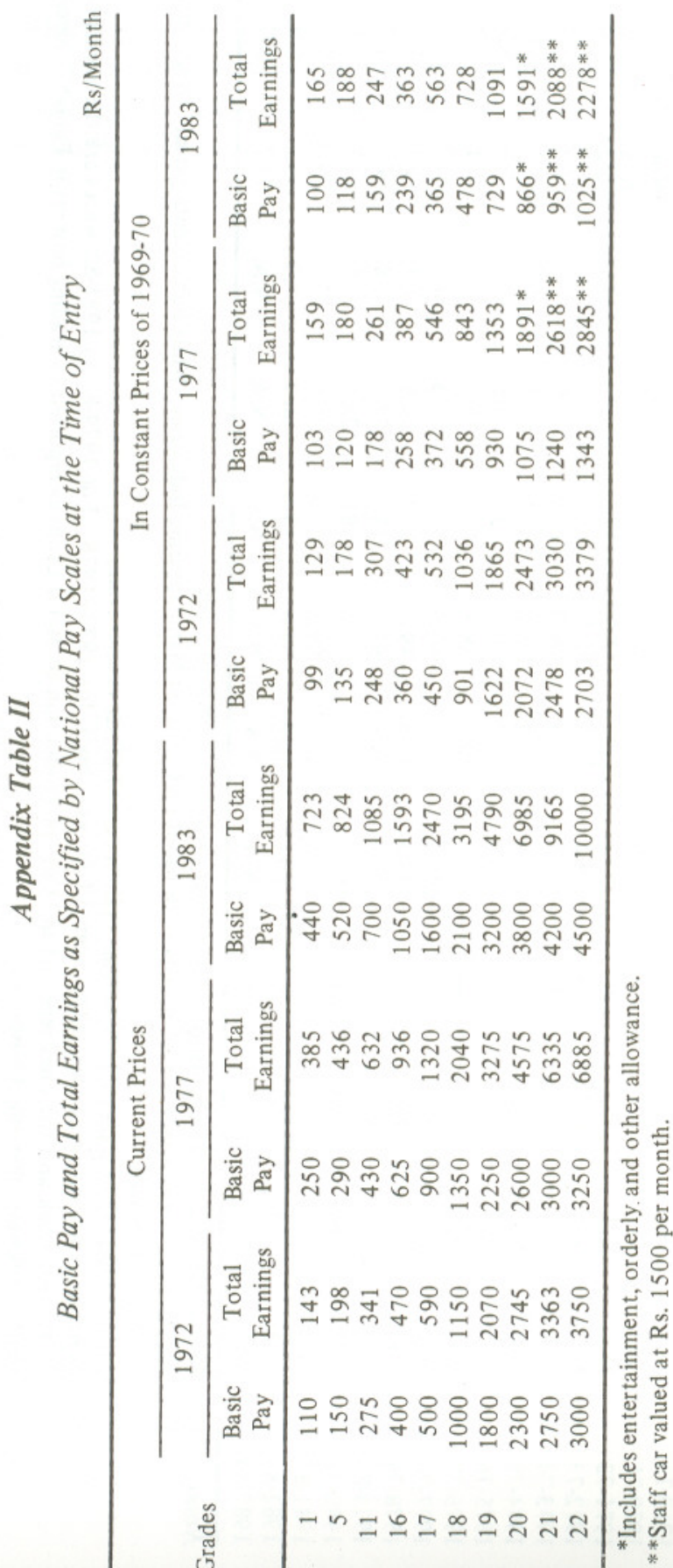

\section{REFERENCES}

1. Ahmed, M. A., and Naeem, A. M. "Real Wages of Production Workers in the Large-Scale Manufacturing Sector of the Punjab, 1972-84". Forthcoming in the Pakistan Manpower Review.

2. Becker S. Gary. Human Capital (2nd ed.), New York: National Bureau of Economic Research. 1975.

3. Guisinger, S. E., and Mohammad Irfan. "Real Wages of Industrial Workers in Pakistan 1954-70”. Pakistan Development Review. Vol. XIII, No. 4. Winter 1974.

4. Guisinger, Stephen, and Norman L. Hicks "Long Term Trends in Income Distribution in Pakistan". World Development. Vol. 6, Nos. 11-12. November-December 1978.

5. Irfan, Mohammad, Lionel Demery and G. M. Arif. "Migration Patterns in Pakistan: Preliminary Results from the PLM Survey 1979”. Islamabad: Pakistan Institute of Development Economics. 1983. (PLM Project Report No. 6)

6. Irfan, Mohammad. "Consequences of Out-Migration on Domestic Labour Market”. 1984. (Mimeographed)

7. Irfan, Mohammad. "Wage Structure in Pakistan". Ph.D. Thesis, Cornell University. 1979.

8. Khan, A. R. "What has been Happening to Real Wage in Pakistan". Pakistan Development Review. Vol. VII, No. 3. Autumn 1967.

9. NESPAK Price Index. Vol. 1, No. 1. July 1974

10. Pakistan. Federal Bureau of Statistics. Monthly Statistical Bulletin. Vol.32, No. 11. November 1984.

11. Pakistan. Federal Bureau of Statistics. Census of Manufacturing Industries Karachi. (Various issues) 


\section{Comments on}

"Real Wages in Pakistan: Structure and Trends 1970-84"'

Dr Mohammad Irfan and Dr Meekal Ahmed are well-known economists of the country. The topic, too, is of great importance not only for the economic theoreticians but also to the economic planners and policy makers.

I must appreciate the authors' commendable job in putting scattered data on wages in one place. It will certainly be of great help to the researchers and policy makers to utilize these data for their own analysis and interpretation. Here, I would like to raise some issues that come to my mind while examining the data.

The comparison of wages in industrial sector (which the authors refer to as formal sector) with the wages in construction sector (which the authors refer to as informal sector) reflects a peculiar relationship as shown below:

\begin{tabular}{ccc}
\hline & $\begin{array}{c}\text { Trends in the Wages in } \\
\text { Industrial Sector in the Punjab }\end{array}$ & $\begin{array}{c}\text { Trends in the Wages } \\
\text { in Construction Sector }\end{array}$ \\
\hline $1972-74$ & Declining & Increasing \\
$1975-78$ & Stagnant & Increasing \\
$1978-83$ & Increasing & Declining \\
\hline
\end{tabular}

Note: It would be more instructive if we could compare the trends in the wages in the industrial sector in the Punjab with the trends in construction sector wages in the same province. Federal Bureau of Statistics (as well as NESPAK) publishes dat by major urban centres. Hence it should be possible to compare data of wages in industrial sectors in the Punjab with the construction sector wages in the same industria

The nagative relationship is curious and needs to be carefully studied and explained.

The comparative trends become more curious if we take into account the fact that wages in industrial sector reflect the labour incomes whereas construction sector data show only the wage rates. This means that construction sector data do not tell how much the labour is earning unless we know how many day-labour gets employed at the reported wage rate. Labour in construction sector is not employed on as regular a basis as it is employed in the industrial sector. Construction sector was witnessing construction boom in 1972-78. It means that the employed days per month for the labour in this sector are not likely to be higher in the 1978-84 period compared to that in the $1972-78$ period. Hence the declining trend in wage rates in the construction sector during $1978-84$ is quite likely reflecting the decline in labour incomes.

How can the increasing trend in the industrial sector be sustained while wages in other urban sectors are declining. This question needs further investigations as it has several implications for the industrial development and growth in the economy.

A more interesting relationship can be seen in the comparison of wages in industrial sector and the wages in agriculture (both refer to the province of Punjab). The relationship has been positive. If we say that industrial wages are determined by agricultural wages, then the question we need to answer is: what determines the movements in agricultural wages? And if we say that there are some common factors that determine the movements in wages in both urban and rural sectors then we need to identify these common factors. ${ }^{1}$

Another interesting point to raise is the regional differences in the daily wage rates quoted for the construction labour. These differences cannot be seen in the paper under review. But the data on regional differences in wage rates are available from the same sources from where the authors have collected data on construction wages. It is curious to see that the growth of wages in the underdeveloped regions is much higher than the growth of wages in the developed regions. Such pattern of growth can have several implications for regional developments and hence needs to be carefully analysed in more detail.

Another issue revealed by the data given in the paper also needs attention. Political regime in early 1970s came with the slogan of redistribution of income and made massive intervention in the labour market. (All this intervention, however, was confined to the formal sector only.) The real wages of production workers failed to respond to this in substantial terms. On the other hand, the real wages in 1976-81 (when government did not try to intervene in the labour market - not even through minimum wage legislations) increased at a rate much higher than what was achieved during 1970-76 through government intervention.

${ }^{1} \mathrm{I}$ am in favour of the latter and $\mathrm{I}$ have given elsewhere my own theory along with empirical analysis. 
Does this mean, government intervention in labour market to improve labour is counter-productive in Pakistan? ${ }^{2}$ Does this mean we should leave labour market free if we want to improve labour welfare? The answer cannot be given by arithmetics of statistics. We need a rigorous analysis of the structure and trends in the labour market in Pakistan.

\section{Professor/Director}

Dr M. Fahim Khan

International Institute of Islamic Economics, International Islamic University, Islamabad

${ }^{2}$ It will be useless to argue that higher wages in the formal sector in late 1970 s came with a decline in employment in the large-scale manufacturing sector unless we can convincingly argue that the labour displaced from manufacturing sector failed to get absorbed anywhere else at the same or better terms. We know that unemployment rate in the economy in 1981 was not worse than that in 1971 and that the growth of real wages in agriculture (where all the surplus labour gets absorbed) increased by 60 percent during the 1976-81 period compared to the 44 -percent increase in the manufacturing sector. 